\title{
Capabilities for Media Graduate Employability: A Case Study of Private Higher Education in South Africa
}

\author{
Fenella Somerville \\ University of the Free State, South Africa \\ Email: fenella@mweb.co.za \\ Address: SARCHi Chair in Higher Education and Human Development, University of the Free State, Bloemfontein, 9301, South Africa
}

\section{Introduction}

Very high levels of youth and graduate unemployment are a concern in South Africa. The national unemployment rate has risen to 29 percent, up from 21.5 percent in 2008 (StatsSA 2019) and currently ranking amongst the highest in the world. A dominant discourse of employability in the context of a global knowledge economy draws a direct link between education, employment, and economic growth (Brown 2003). Accordingly, higher education plays an instrumental role in producing graduates as human capital whose value lies in increasing productivity for economic gain (Becker 1962; Schultz 1962). The importance of a job in enabling a better future has driven increased demand for higher education, fueled by high expectations of the potential of a qualification to realize students' aspirations. However, when graduates enter the labor market, they face barriers grounded on influences beyond the control of higher education. Rapidly-evolving technology is transforming and impacting on all industries. The amalgamation of the media and technology industries is leading to redundancy and restructuring on the one hand, and creative, new work opportunities on the other (World Economic Forum, 2016). As a result, higher education faces a daunting challenge preparing graduates for this disrupted and disrupting market.

\section{The Quest}

This study challenges our understanding of employability and the reliance on higher education to prepare graduates to meet employers' needs. Private higher education in South Africa is a relatively small, yet diverse sector. Institutions range in size, form, and target constituency, but they are all predominantly commercial entities that deliver vocational and practical programs at the undergraduate level (Levy 2003). Employment is important for the livelihood and well-being of graduates and their families. But is this responsibility solely that of higher education? And what happens in a constrained economy when the supply of graduates exceeds employers' demands or their budgets? The capability approach prioritizes the needs of people over the economy (Sen 1999), and I use it as an evaluative framework to understand the range of realities of media graduates' journeys in the workplace and the factors that differentially enable or constrain their careers and life paths.

\section{The Methodology}

Using a mixed methods sequential exploratory design within a transformative paradigm, the project explores the employment experiences of media graduates from three private higher education institutions in South Africa. The qualitative phase of the study comprised individual, semi-structured interviews conducted with twenty-one media graduates, four key informants from the institutions, and six media employers. These interviews produced in-depth perspectives on graduate transition and participation in the current media work space. The rich qualitative data 
underpinned the quantitative phase, which took the form of an electronic survey conducted with 2,746 media graduates. The survey produced a wider profile of private higher education media graduates and a broader understanding of their values, opportunities, and well-being as media practitioners.

\section{The Contribution}

Globalization and the commodification of knowledge have prioritized employability as a function of higher education worldwide (Tomlinson 2012). Nations compete for global standing, yet local education systems face pressures particular to their socio-economic, political, and historic contexts. Higher education serves a purpose beyond preparing graduates as labor, with ethical and moral obligations to individuals as well as to society (Boni and Walker 2016; McCowan 2015). Much of the research on employability and higher education has emerged from public universities (Walter and Fongwa 2017; Tomlinson 2012). Based on the different stakeholder perspectives and the actual experiences of graduates, this small-scale study provides insight into the role of private higher education in the realization of media graduate employability and well-being. The value of this study lies in presenting a perspective from the global South and the specific context of private higher education in South Africa.

\section{The Main Take-Away}

The data shows that graduates feel the practical and industry-relevant programs delivered by private institutions prepared them well enough to function in the dynamic field of media. Institutions provide graduates with skills, knowledge, and ready access to industry networks. Yet, employment outcomes are not the same for all the graduates, and even skilled and agile candidates from reputable institutions may not find employment. Employers in media organizations indicate that they no longer expect fully work-ready graduates as they increasingly try just to keep up with the rapid changes in digital technology. This study prompts new understandings of the meaning of employability beyond individually embodied attributes to meet employers' needs. Employability depends to a great extent on the ability of agentic and adaptable individuals to be able to establish connections and collaborate with existing structures in order to find employment or to create new opportunities that help shape the evolving work space.

\section{References}

Becker, Gary S. 1962. "Investment in Human Capital: A Theoretical Analysis." Journal of Political Economy 70(5): Investment in Human Beings: 9-49. https://www.jstor.org/stable/i304799.

Boni, Alejandra, and Melanie Walker. 2016. Universities and Global Human Development: Theoretical and Empirical Insights for Social Change. London: Routledge.

Brown, Phillip. 2003. "The Opportunity Trap: Education and Employment in a Global Economy." European Educational Research Journal 2(1): 141-179. doi:10.2304/eerj.2003.2.1.4.

Levy, Daniel C. 2003. "Profits and Practicality: How South Africa Epitomizes the Global Surge in Commercial Private Higher Education." PROPHE Working paper (2). http://www.albany.edu/ prophe/.

McCowan, Tristan. 2015. "Should Universities Promote Employability?" Theory and Research in Education 13(3): 267-285. doi:10.1177/1477878515598060.

Sen, Amartya. 1999. Development as Freedom. Oxford: Oxford University Press.

Schultz, Theodore W. 1961. "Investment in Human Capital." The American Economic Review 51(1): 1-17. http://www.jstor.org/stable/1818907. 
StatsSA. 2019. Quarterly Labour Force Survey. Quarter 2. Pretoria: Statistics South Africa. http://www.statssa.gov.za/?page_id=1854\&PPN=P0211.

Tomlinson, Michael. 2012. "Graduate Employability: A Review of Conceptual and Empirical Themes." Higher Education Policy 25: 407-431. https://link.springer.com/article/10.1057/hep.2011.26.

Walker, Melanie, and Samuel Fongwa. 2017. Universities, Employability and Human Development. London: Palgrave Macmillan.

World Economic Forum. 2016. "Digital Transformation of Industries: Media, Entertainment and Information." WEF White Paper. http://reports.weforum.org/digital-transformation/media/. 